\author{
Marta Kaczmarek, Paulina Piskorz \\ Uniwersytet Łódzki \\ marta.k516@gmail.com,paulinapiskorz@interia.pl
}

\title{
Techniki marketingu politycznego wykorzystane przez brytyjską Partię Konserwatywną w kampanii wyborczej w 2010 roku
}

\begin{abstract}
Streszczenie: Celem niniejszego artykułu jest dogłębna analiza czynników marketingowych, które przyczyniły się do sukcesu Partii Konserwatywnej podczas wyborów w 2010 roku. Kampania ta znacząco różniła się od poprzednich i zastosowano w niej wiele technik marketingu politycznego, które dotąd w Wielkiej Brytanii w ogóle nie używano. Autorki zaprezentowały wszystkie formy promocji wykorzystane przez zwycięską partię - slogany, plakaty i billboardy, reklamy w Internecie, debaty telewizyjne oraz reklamy negatywne, wymierzone w głównego konkurenta Konserwatystów, czyli rządzącą wówczas Partię Pracy. Artykuł przedstawia kontrast między formami marketingowymi stosowanymi przez Partię Konserwatywną przed i po 2010 roku oraz analizuje, w jaki sposób wpłynęły one na zmianę wizerunku Torysów, który w oczach społeczeństwa brytyjskiego już od wielu lat pozostawał bardzo negatywny.
\end{abstract}

Brytyjska kampania wyborcza z 2010 r. była pod wieloma względami wyjątkowa i wyróżniała się na tle poprzednich, także pod względem marketingowym, który różni się od bardziej popularnego modelu amerykańskiego. W 2010 r. w Wielkiej Brytanii po raz pierwszy w historii zorganizowano debaty wyborcze, które już od kilkudziesięciu lat są nieodłącznym elementem kampanii wyborczych w USA. Co ważne, w debatach tych, oprócz liderów dwóch największych partii, wziął też udział Nick Clegg, szef Partii Liberalnej, która okazała się prawdziwą „trzecią siłą” brytyjskiego systemu politycznego i stała się wreszcie równym graczem dla labourzystów i konserwatystów (Gazeta Wyborcza, 2010). Przeprowadzone w lutym 2010 r. przez The Times badania opinii publicznej wykazały, że 70\% wyborców uważało, że Wielka Brytania jest „zrujnowana”, 64\% Brytyjczyków było zdania, że ich kraj „zmierza w złym kierunku” (Press Europ, 2010). 
W zaistniałej sytuacji pesymizmu i kryzysu zaufania Brytyjczyków, Partia Konserwatywna po raz pierwszy od 13 lat stanęła przed realną szansą na przejęcie władzy.

Na wstępie należy podkreślić, że marketing polityczny w Wielkiej Brytanii znacząco różni się od tego znanego z USA, choć w ostatnich latach obserwuje się znaczną amerykanizację brytyjskiego dyskursu politycznego. Po pierwsze, w Wielkiej Brytanii odpłatna polityczna reklama w telewizji jest prawnie zakazana, przez co partie są o wiele bardziej ograniczone przez prawo wyborcze. Zasada ta uformowała się wraz z powstaniem BBC, a obecnie wyrażona jest w Communication Act z 2003 r., zgodnie z którym reklamy nie mogą być tworzone przez organy, których cele są całkowicie lub głównie polityczne. Z tego powodu reklamy polityczne w Wielkiej Brytanii przybierają na ogół formy plakatów lub billboardów, dlatego też powstała forma kompensacji strat zakładająca istnienie dwóch form nadawanych bezpłatnie w publicznej telewizji nagrań wyborczych - Party Policital Broadcasts (PPBS) oraz Party Election Broadcasts (PEBs) (Foster, 2010: 160), które jednak znacznie różnią się od standardowych spotów wyborczych.

Przygotowaniem kampanii Partii Konserwatywnej zajęła się firma Euro $R S C G$, do której dołączyła później agencja $M \& C$ Saatchi. Prowadzono kilka głośnych kampanii outdoorowych na skalę ogólnokrajową, a do małych, mniej znaczących okręgów wyborczych starano się dotrzeć za pomocą marketingu bezpośredniego i mailingu (Parsons, 2010). Hasłem wyborczym Partii Konserwatywnej w 2010 był slogan: „Głosuj na zmianę. Głosuj na PK”. Jednakże Konserwatyści niezmiennie mieli kiepski wizerunek. Większość ciągle postrzegała ich jako snobistycznych arystokratów, którzy nie mają pojęcia o codziennych problemach przeciętnych Brytyjczyków. Jednak ich lider, David Cameron, był dość popularny, a z pewnością o wiele bardziej popularny niż jego partia. Dlatego też Konserwatyści zadecydowali, że to Cameron będzie twarzą ich kampanii billboardowej. Pierwsze plakaty przedstawiały opalonego lidera Torysów zachęcającego do głosowania na jego partię. Miały one wzbudzać pozytywne wrażenia wśród wyborców, a celowym zabiegiem było wykorzystanie elementów w kolorze niebieskim, który osłabia napięcie, nastraja marzycielsko, łagodzi nerwy; kojarzy się z niebiańskością, perspektywicznością, ładem, porządkiem, nowoczesnością, otwartością na zmiany (Pacuła, 2011). Jednak plakaty te ośmieszyły Camerona. Brytyjczyków rozbawił fakt, że fotografie zostały komputerowo zretuszowane tak, że lider Partii Konserwatywnej wyglądał znacznie młodziej niż w rzeczywistości. Stworzono specjalną stronę, MyDavidCameron.com, gdzie można było umieszczać parodie plakatu Camerona, na których przedstawiano go m.in. twierdzącego, że „niektórzy z jego najlepszych przyjaciół są biedni" lub jako figurę woskową z muzeum Madame Tussaud (Lorenz, 2010). 
Ważną rolę w kampanii Partii Konserwatywnej odegrały plakaty wyborcze z wizerunkami „przeciętnych obywateli”, wyglądających bardziej na tradycyjnych zwolenników Partii Pracy, którzy, jak głosiły przedstawione na nich slogany, „nigdy wcześniej nie głosowali na Torysów”. Plakaty te przedstawiały m.in. pracowników fizycznych, młodą czarnoskórą dziewczynę, matkę z dwójką dzieci itp. opatrzone napisami: „Nigdy wcześniej nie głosowałam na Torysów, ale podobają mi się ich plany pomocy rodzinom"; „ale musimy zająć się gospodarką”; „musimy naprawić nasze społeczeństwo". Reklamy te miały na celu przybliżyć Partię Konserwatywną do wyborców, poszerzyć grono wyborców Torysów oraz pokazać, że także przejmują się losem zwykłych ludzi. PK chciała wykorzystać fakt, że Brytyjczycy, w tym zwolennicy Partii Pracy, są niezadowoleni z sytuacji swojego kraju, przy czym PK zwracała uwagę na różne elementy swojego programu wyborczego i zachęcała do zapoznania się z jego treścią.

Wizerunek Konserwatystów w Wielkiej Brytanii nie zmieniał się przez dłuższy czas, przez co postrzegano ich jako staroświeckich spadkobierców „żelaznej damy”. Zmiany społeczno - kulturalne zachodzące bardzo dynamicznie w Wielkiej Brytanii spowodowały, odsunięcie się od idei konserwatywnej, a Partia Konserwatywna zaczęła tracić poparcie. Oprócz niesprzyjającej sytuacji społecznej, Konserwatystów osłabiało to, że nie potrafili wykorzystać potencjału nowoczesnego marketingu czy nowych technologii.

Rewolucja nadeszła wraz z Davidem Cameronem. Dużą dyskusję wywołały wprowadzone przez niego zmiany programowe i ideologiczne (m.in. zrezygnował z obniżki podatków, skierował się ku polityce proekologicznej, domagał się zwiększenia wydatków na rzecz walki z ubóstwem w krajach Trzeciego Świata). Ważnym krokiem było poparcie dla homoseksualistów (Zychowicz, 2012). Od 2005 roku na listach wyborczych konserwatystów można było spotkać coraz więcej kobiet i przedstawicieli mniejszości rasowych (Krok, 2010). Te działania kosztowały Camerona konflikt ze starszymi działaczami partii, jednak ukazały, że Konserwatyści są zdolni do zmian, otwarci na świat. Był to odważny i skuteczny pierwszy krok do odzyskania dawnej pozycji.

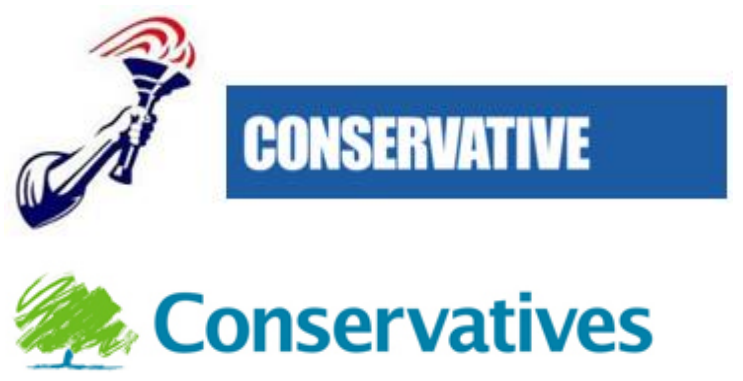

Źródło: www.chewdesign.co.uk 
Podejście Konserwatystów do marketingu także w znacznym stopniu się rozwinęło. Pierwszą zmianę można było zauważyć już w 2006 roku, kiedy zaprezentowano nowe logo. Agresywnie wzniesioną rękę z pochodnią zastąpiono drzewem rysowanym miękką kreską.

Logo dokładnie odzwierciedliło nowy kierunek partii, przy czym stwarzało wrażenie delikatniejszego i spokojniejszego od poprzedniego. Nowy projekt strony internetowej i internetowy pamiętnik Camerona to kolejne kroki, które przyciągnąć miały nowoczesnego wyborcę. Duże wrażenie, szczególnie na młodych ludziach, zrobiła również reklama Konserwatystów na popularnym serwisie muzycznym Spotify (Hall, 2009: 14). Obecność w Internecie została szybko zauważona i wpłynęła znacznie na postrzeganie partii. Otwarcie się na komunikację internetową było jednak dopiero początkiem zmian marketingowych.

David Cameron wprowadził do kampanii dwa kluczowe elementy. Kluczowe, ponieważ w dużej mierze przesądziły o zwycięstwie Partii w wyborach w 2010 roku (Green, 2010: 667-688). Pierwszym elementem był udział w debatach, drugim - reklama negatywna.

Debaty wyborcze w Stanach Zjednoczonych cieszą się ogromną popularnością, często są punktem kulminacyjnym kampanii i przesądzają o wyniku wyborczym. Nie można więc powiedzieć, że taka forma dialogu politycznego jest marketingową nowością, jednak w Wielkiej Brytanii aż do roku 2010 debat nie stosowano. Brytyjscy wyborcy przyjęli zapowiedź debat z ciekawością. Zaskoczeniem był fakt, że oprócz przedstawicieli dwóch największych partii, miał w nich wziąć udział również lider Liberalnych Demokratów.

Tematem pierwszej debaty była polityka wewnętrzna. Ku zdumieniu obserwatorów zarówno David Cameron jak i Gordon Brown zostali całkowicie przyćmieni przez wystąpienie Nicka Clegga. Ukazał się on jako młody, otwarty, inteligentny polityk, który daje Brytyjczykom nowe możliwości. Mimo iż David Cameron prezentował się elegancko, mówił płynnie, bez notatek, to niestety był przewidywalny i nie potrafił przekazać swoich idei. Nastąpił duży wzrost poparcia dla Liberalnych Demokratów, którzy stali się równorzędnymi przeciwnikami Torysów i Laburzystów (Shirbon, 2010). Zarówno Cameron jak i Brown prowadzili swoje kampanie w całym kraju, odwiedzając kolejne fabryki i okazując zainteresowanie gospodarką. Okazało się jednak, że większy wpływ na opinię publiczną ma telewizyjna debata. Po uświadomieniu sobie tego faktu oraz mając nowego, groźnego przeciwnika, Cameron i Brown przygotowali się do kolejnych debat nieco staranniej.

Tematem drugiej debaty były sprawy zagraniczne. Dało się zauważyć zwiększony atak liderów dwóch największych partii na Nicka Clegga. Mimo iż Brown zrobił największy widoczny postęp wśród mówców, nie przełożyło się to na wynik debaty. The Sun, The Daily Express czy The Times stwierdzały nieznaczną wygraną Camerona (BBC News, 2010), jednak większość 
mediów ogłosiła remis pomiędzy Cameronem i Cleggiem. Podczas drugiej debaty lider Partii Konserwatywnej całkowicie zmienił taktykę. W pierwszej debacie stał pośrodku, co zmuszało go do zwracania się raz do jednego, a raz do drugiego przeciwnika politycznego. Tym razem, stojąc po lewej, dzięki mowie ciała i odpowiednim wypowiedziom stworzył zauważalną barierę: „ja - oni”. Zauważono, że opanował emocje dużo lepiej niż podczas pierwszej debaty, podnosząc głos jedynie w sprawie fałszywych oskarżeń wysuwanych przez Gordona Browna. Cameron z łatwością posługiwał się żartem sytuacyjnym, stosował skuteczne techniki retoryczne (często powtarzał zwrot "gdybym był premierem”, snuł też plany co do ewentualnej koalicji z Liberalnymi Demokratami) (Porter, Winnett, 2010).

Ekonomia i podatki to temat trzeciej, finałowej debaty, która okazała się wielkim sukcesem Davida Camerona. Gordon Brown nie wytrzymał presji i zaprzepaścił szansę na poprawę notowań. Jego ataki na Camerona odebrano za zbyt agresywne, podczas gdy lider Konserwatystów zachował spokój i nie dał się sprowokować (Wintour, Curtis, 2010). Nick Clegg poległ na kwestii imigrantów, nie był już również tak pewny siebie jak w pierwszej debacie. Badania przeprowadzane po ostatniej debacie zaczęły wskazywać coraz bardziej wyraźną przewagę Partii Konserwatywnej nad Partią Pracy (Richardson, 2010). Debata finałowa była więc swoistym „rzutem na matę", punktem kulminacyjnym kampanii, który przekonał niezdecydowanych wyborców właśnie do Konserwatystów.

Drugim nowym elementem kampanii Camerona była reklama negatywna. Jest to bardzo skuteczne narzędzie marketingu, ponieważ gra na silnych emocjach. Szok, oburzenie, uśmiech - niezależnie od reakcji odbiorcy, reklama z pewnością pozostaje zapamiętana. Nieumiejętne stosowanie reklamy negatywnej może jednak przynieść szkody. Zbyt dużo agresji, fałszywe zarzuty czy mało inteligentne żarty mogą obniżyć wiarygodność tego, kto ich używa.

Konserwatyści rozpoczęli kampanię negatywną od cyklu billboardów. Przedstawiały uśmiechniętego premiera, Gordona Browna, w towarzystwie takich haseł jak: „Wypuściłem wcześniej z więzienia 80 tys. więźniów. Głosuj na mnie!” czy „Podwoiłem dług narodowy. Głosuj na mnie!”. W drugim etapie kampanii, zamiast dopisku „Głosuj na mnie!” pojawił się jeszcze bardziej dobitny: „Pozwól mi to zrobić jeszcze raz” (Williams, 2010). Tak skonstruowany przekaz, oparty na kontraście i konkretnych zarzutach, miał nie tylko zdyskredytować Laburzystów. Tematy, które poruszono na billboardach dotykały zwykłych Brytyjczyków. Konserwatyści odgrywali więc rolę "głosu ludu”, którego bolą nadużycia władzy. Było to symboliczne zejście $\mathrm{z}$ piedestału, którego $\mathrm{w}$ danym momencie Torysi bardzo potrzebowali. Kampania była dla niektórych wyborców za mocna, jednak mimo wszystko działała na korzyść Konserwatystów, bo pobudzała społeczeństwo do dyskusji. 
Warto wspomnieć, że oprócz zaplanowanych posunięć marketingowych, Torysi bardzo szybko reagowali na bieżące wydarzenia i wykorzystywali je w kampanii. Zdjęcie Gordona Browna odwiedzającego szpital w Manchesterze było idealnym materiałem do walki politycznej. Widać na nim, jak specjaliści od PR-u pracujący dla Browna przytrzymują mu drzwi. Celem tego zabiegu było uzyskanie lepszego ujęcia dla telewizyjnych kamer (The Guardian, 2010). Konserwatyści nadali fotografii zupełnie odmienny sens, dołączając do niej hasło „Witamy w Manchesterze Wasza Wysokość!”. Dopełnieniem plakatu było zdanie „6 maja pokaż Laburzystom drzwi”. Konserwatyści nie tylko wykazali się inteligentnym humorem, ale ukazali również, że snobizm, o który ich oskarżano, jest domeną Browna.

Dzięki kampanii prowadzonej w nowoczesny sposób, wizerunek Partii Konserwatywnej uległ dużej zmianie. Nowe narzędzia docierania do odbiorców oraz odważniejsze formy marketingu spowodowały, że Konserwatyści wreszcie zaczęli być postrzegani jako partia idąca z duchem czasu, wiarygodna, bliska zwykłym ludziom. Działania marketingowe Partii Konserwatywnej okazały się skuteczne - Torysi ostatecznie wygrali wybory parlamentarne z wynikiem $36,1 \%$, jednak nie pozwoliło im to na uzyskanie większości, przez co konieczne było utworzenie koalicji z Partią LiberalnoDemokratyczną. Postawa Davida Camerona w trzech debatach, jego zwycięstwo w ostatniej oraz znaczne zmiany programowe, a także konsekwentne działania nakierowane na zmianę wizerunku Torysów pomogły Partii Konserwatywnej przejąć władzę w Wielkiej Brytanii. Humorystyczna kampania negatywna była również jednym z czynników, który przyczynił się do wygranej Partii Konserwatywnej w wyborach w 2010 roku, zwłaszcza że plakaty pozytywne Torysów zostały wyśmiane przez Brytyjczyków. Konserwatyście zręcznie uwypuklili słabości ówczesnego rządu i kontrowersje wokół osoby labourzystowskiego premiera, które znajdowały swoje odzwierciedlenie w rzeczywistości.

\section{Bibliografia}

Foster, Steven. Political Communication. Edinburgh: Edinburgh University Press Ltd, 2010.

Green, Jane. Strategic Recovery? The Conservatives under David Cameron. Parliamentary Affairs 4 (2010): 667-688.

Hall, Emma. “Tories Try Marketing to Shake Stodgy Image”. Advertising Age 37 (2009): 14.

Krok, Tomasz. „Konserwatyzm A.D.2010”. Conservative Salon 24.09.2010. (http://conservative. salon24.pl/225588,konserwatyzm-a-d-2010, dostęp 19.11.2012).

Lorenz, Wojciech. „Internetowa parodia psuje kampanię Torysom”. Rzeczpospolita III 2010. (http://archiwum.rp.pl/artykul/929524_Internetowa_parodia_psuje_kampanie_torysom. html, dostęp 5.09.2011).

Pacuła, Jarosław. „Językowe i pozajęzykowe komponenty marki politycznej”. Media i społeczeństwo nr 1/2011. (http://www.mediaispoleczenstwo.ath.bielsko.pl/art/133_ pacula.pdf, dostęp 16.11.2012). 
Parsons, Russel. "Conservative Party Appoints M\&C Saatchi". Marketing Week 2010. (http://www.marketingweek.co.uk/conservative-party-appoints-mc-saatchi/3011590. article, dostęp 16.11.2012).

Porter, Andrew, Winnett, Robert. "General Election 2010: David Cameron Fights Back in Second Leaders' Debate”. The Telegraph 23.04.2010. (http://www.telegraph.co.uk/ news/election-2010/7621644/General-Election-2010-David-Cameron-fights-back-insecond-leaders-debate.html, dostęp 19.11.2012).

Richardson, Miranda. "Polls Suggest Cameron Wins Final Debate". Sky News 30.04.2010. (http://news.sky.com/story/775818/polls-suggest-cameron-wins-final-debate, dostęp 19.11.2012).

Shirbon, Estelle. "Outsider Clegg Judged Winner in First UK TV debate”. Reuters 15.04.2010. (http://www.reuters.com/article/2010/04/15/us-britain-election-idUSTRE63E4S920 100415, dostęp 19.11.2012).

Williams, Matt. "Tory Party Launches Second Phase of Brown-bashing Campaign". Campaign 13.04.2010. (http://www.campaignlive.co.uk/news/996249/gallery/7322/page/2/ \#7322, dostęp 19.11.2012).

Wintour, Patrick, Curtis, Polly. "Election Debate: David Cameron Wins Third Leg". The Guardian. 30.04.2010. (http://www.guardian.co.uk/politics/2010/apr/30/leadersdebate-david-cameron-wins-third-leg, dostęp 19.11.2012).

Zychowicz, Piotr. "Gdzie są angielscy konserwatyści?" Rzeczpospolita. 26.07.2012 (http://www.rp.pl/artykul/919382.html?print=tak\&p=0, dostęp 19.11.2012).

Kto naprawi Wielkq Brytanię? (http://www.presseurop.eu/pl/content/news-brief/186251kto-naprawi-wielka-brytanie, dostęp 12.06.2012).

Papers Divided over Verdict on Second Leaders Debate. BBC News. 23.04.2010. (http:// news.bbc.co.uk/2/hi/uk_news/8638994.stm, dostęp 19.11. 2012).

"Tories Slam the Door on Brown". The Guardian. 15.04.2010. (http://www.guardian.co.uk/ media/mediamonkeyblog/2010/apr/15/election-conervatives-labour-brown-poster, dostęp 19.11.2012).

"Wybory w Wielkiej Brytanii. Brown jest jak zmęczony urzędnik, nie mąż stanu". Gazeta Wyborcza. (http://wiadomosci.gazeta.pl/wiadomosci/1,114873, dostęp 6.12. 2012).

\section{Political Marketing Techniques used by the British Conservative Party in the 2010 Election Campaign}

Summary

The purpose of this essay is a thorough analysis of marketing factors that have contributed to the success of the Conservative Party in 2010 general election. The campaign was significantly different than those known before, and new techniques of political marketing that had not been used in United Kingdom until that time were introduced. The authors have presented all forms of promotion used by the winning party - slogans, posters and billboards, advertising on the Internet, television debates and negative advertising, targeting the main opponent of the Conservatives, that is the ruling Labour Party. The paper presents contrast between marketing tools used by the Conservative Party before and after 2010 as well as analyses their impact on the altered image of the Tories, that for many years have been negatively perceived in the British society. 